\title{
Treatment planning for Interstitial Photodynamic Therapy for head and neck cancer
}

\author{
RLP van Veen ${ }^{1 *}$, DJ Robinson ${ }^{1}$, HJCM Sterenborg ${ }^{1}$, JB Aans ${ }^{1}$, IB Tan ${ }^{2}$, O Hamming Vrieze ${ }^{3}$, F Hoebers $^{3}$, MJH Witjes ${ }^{4}$, \\ PC Levendag ${ }^{5}$
}

From 2nd Scientific Meeting of the Head and Neck Optical Diagnostics Society

San Francisco, CA, USA. 23-24 January 2010

We are investigating the feasibility of interstitial (iPDT), using multiple linear light sources positioned within the tumour. In an on-going feasibility study, 16 patients with incurable SCC at the base tongue have been treated with iPDT as a last treatment option. Preliminary results are encouraging with a long-term complete response in 8 out of 16 patients who have failed standard treatment. There is strong evidence that the partial responders are a direct result of inadequate light delivery. Accurate light dosimetry has not yet been performed during iPDT in head and neck, we therefore propose the development of dedicated iPDT verification and planning technology to improve the clinical response and reduce the occurrence of side effects.

We propose to develop a 3-step approach: 1) Pretreatment planning, based on MRI in which a tumour and a risk volume are identified. A simple planning algorithm will then estimate the optimal positions, amount and lengths of the linear light sources. 2) Verification 3D imaging e.g. X-ray C-arm of the source locations after placement, 3) Modification of the pretreatment planning based on the actual source locations. The modification step will be executed in two phases; initially aiming to implement a simple planning strategy. This approach will be based on iPDT induced tissue damage and does not take into account any patient specific PDT parameters. In the second phase we aim to investigate methods to measure the actual light transport within the tumour and risk volumes. These measurements enables for a patient tailored inverse planning strategy aiming for improved accuracy. The performance of the proposed planning strategies and

'Erasmus MC, Center for Optical Diagnositcs and Therapy, Rotterdam, The Netherlands

Full list of author information is available at the end of the article their clinical results will be evaluated by mutual comparison and previous results.

The clinical results so far indicate good conservation of functions i.e. swallowing, and excellent local control of the tumour. Interstitial PDT may offer an excellent alternative or adjuvant for conventional treatment modalities.

\section{Author details}

'Erasmus MC, Center for Optical Diagnositcs and Therapy, Rotterdam, The Netherlands. ${ }^{2}$ Netherlands Cancer Institute, ENT, Amsterdam, The

Netherlands. ${ }^{3}$ Netherlands Cancer Institute, Radiotherapy, Amsterdam, The Netherlands. ${ }^{4}$ University Hospital Groningen, Oral and Maxillofacial Surgery, Groningen, The Netherlands. ${ }^{5}$ Erasmus MC, Radiotherapy, Rotterdam, the Netherlands.

Published: 29 October 2010

doi:10.1186/1758-3284-2-S1-045

Cite this article as: van Veen et al:: Treatment planning for Interstitial

Photodynamic Therapy for head and neck cancer. Head \& Neck Oncology 2010 2(Suppl 1):045.
Submit your next manuscript to BioMed Central and take full advantage of:

- Convenient online submission

- Thorough peer review

- No space constraints or color figure charges

- Immediate publication on acceptance

- Inclusion in PubMed, CAS, Scopus and Google Scholar

- Research which is freely available for redistribution

Submit your manuscript at www.biomedcentral.com/submit
C Biomed Central 